\title{
The Evolution and Applications of Balanced Scorecard: A Comparative Approach
}

\author{
Mohamed A. K. Basuony \\ The American University in Cairo, Egypt \\ Ain Shams University, Egypt \\ Medhat N. El Guindy \\ American University in Dubai, UAE \\ Tanta University, Egypt
}

\begin{abstract}
This paper presents and demonstrates the Balanced Scorecard (BSC) by adopting two approaches. The first approach focuses on the evolution of the BSC and its applications in private and public, government $\&$ non-profit organizations. The second approach compares four related tools which can help organizations articulate and cascade their strategies. The main focus of this paper is to compare the BSC to three other tools in order to demonstrate the value of the BSC from different points of view. First, the BSC and Tableau de Bord are compared from the point of view of the performance measurement system. Second, the BSC and Executive Information System are compared from the point of view of the strategic management system. Finally, the BSC and Budgeting are compared from the point of view of the control system.
\end{abstract}

Keywords: Balanced Scorecard, Tableau de Bord, Executive Information System, Budgeting, performance measurement, strategic management system

\section{Introduction}

Traditional performance measurement spotlights on financial measures rather than non-financial measures. They focus on the financial assets of the firm. However, financial directors want to measure and respond to intangible assets which are of worth to the firm because of their significant effect on the bottom line (Oliveira, 2001). When managers focus firmly on enhancing tangible assets, they frequently miss the opportunity to evaluate and grow the intangible assets needed to make the most value to a customer over a lifetime.

Weaknesses of traditional measurement systems revolve around the following key issues: financial measures concentrate on short-term objectives; many key non-financial performance measures are ignored; financial measurements are not in tune with strategic objectives and are not customer driven.

A performance measurement system that depends only on financial reporting indicators is concentrating on past performance and a short- term plan. Managers need more than traditional performance measures to be applied in their firms (Basuony, 2014b; McCunn, 1998). However, firms need to deal with the future not just knowing about the past performance. This requires a better understanding of long-term objectives which can drive future success. The combination between financial and non-financial measures and short and long-term goals can help an organization achieve its vision and strategy. 
Therefore, the BSC has emerged to overcome these deficiencies by mixing financial and non-financial measures.

The rest of the paper is organized into three sections: section two discusses the evolution of the BSC. Section three compares between the BSC other tools which are Tableau de Bord, Executive Information System and budgeting. Finally, sections four provides summary and conclusions.

\section{The evolution of the BSC}

The BSC was initially planned to overcome the limitations of the management of only financial measures which report outcomes but do not discuss the drivers of future performance. The BSC was introduced by Kaplan and Norton in 1992 in order to concentrate business focus on measuring the performance. Four different key perspectives were recognized to be critical and provide the framework of BSC. The four perspectives of BSC are financial, customer, internal process, and learning and growth. Figure (1) presents these four perspectives of BSC.

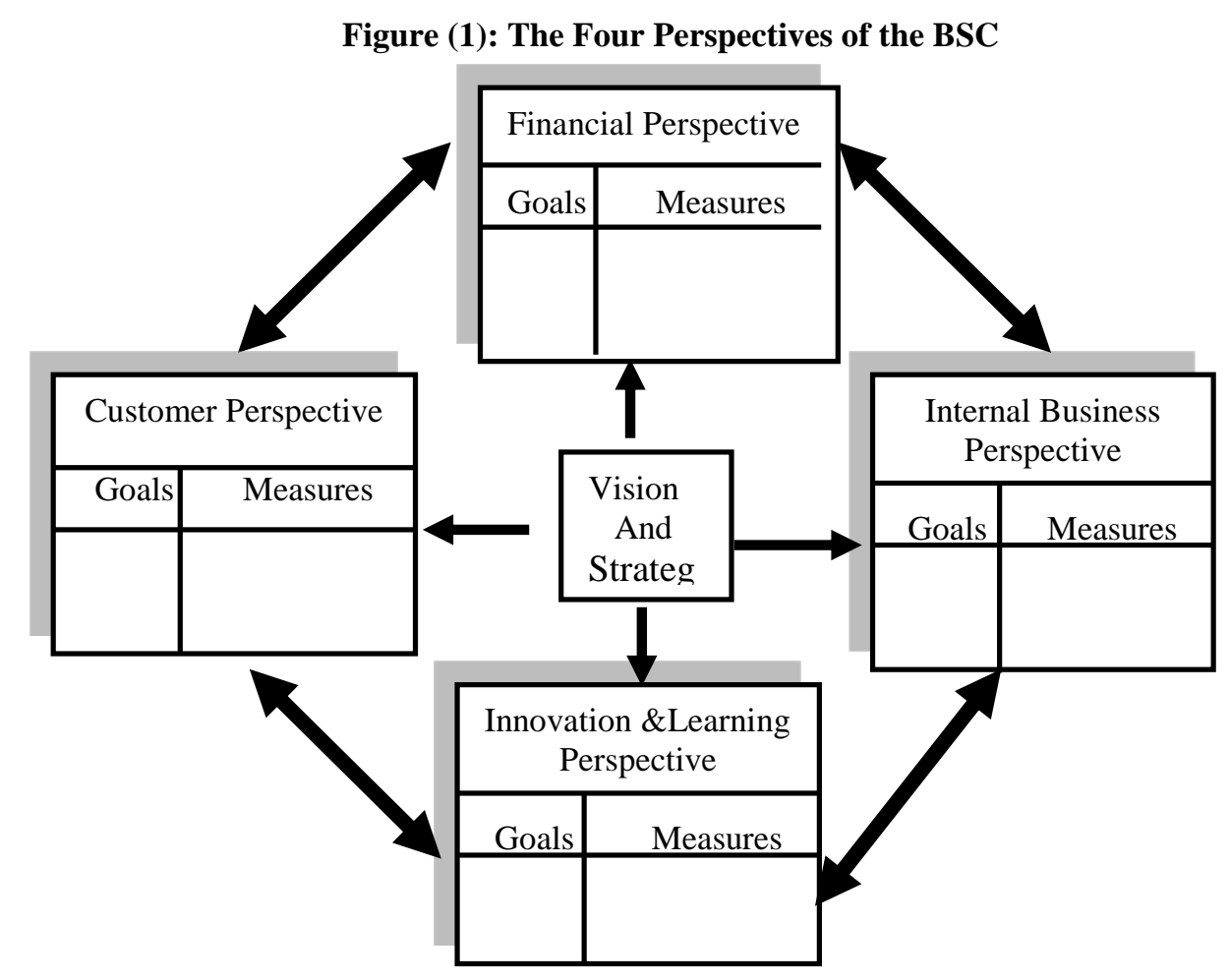

Source: Kaplan, R. and Norton, D. (1992)

The BSC has evolved over time. In 1996, Kaplan and Norton developed the model in their view linking and aligning the BSC with the strategy of the firm. They proposed four interconnected management processes to translate the strategy into objectives and then transformed to measures or indicators. These processes are: clarifying and translating vision and strategy; communicating, alignment and linking strategic objectives and indicators; business planning and target setting; and, enhancing strategic feedback and learning. Figure (2) shows the BSC as a strategic management system.

In their studies of 2001 and 2004, Kaplan and Norton discussed further stages of the BSC evolution. They introduced five principles to keep strategy as they concentrate on organizational management 
processes and strategy mapping. Their evolution encompasses a strategic management and control system. This evolution of BSC reflects its implementation and application.

Figure (2): The BSC as a Strategic Framework for Action

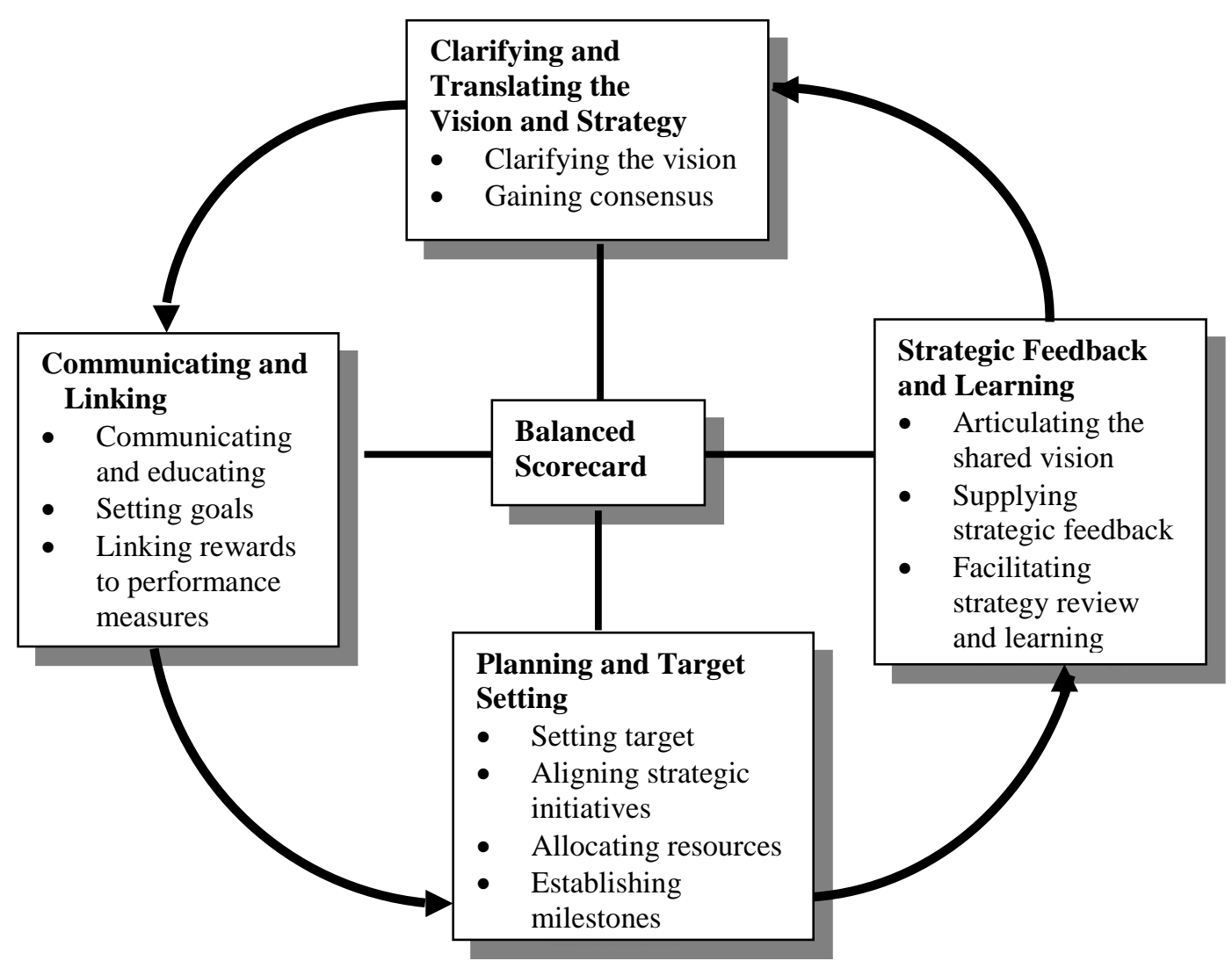

Source: Kaplan, R. and Norton, D. (1996a)

\subsection{Evolution of the BSC in Private and Public Sectors}

This section offers a critical analysis of the applications of the BSC in private organizations and in more details for public, government and nonprofit organizations.

\subsubsection{Applications of the BSC in Private Organizations}

The BSC was started in the private sector and evolved over time from measuring to managing performance. The four perspectives of BSC link and communicate in a chain of cause-and-effect relationships. Enhancing and aligning intangible assets leads to enhance performance which, in turn, drives success for customers and shareholders. Figure (3) shows the links among the four perspectives of BSC. 
Figure (3): The BSC Framework in Private-Sector Organizations

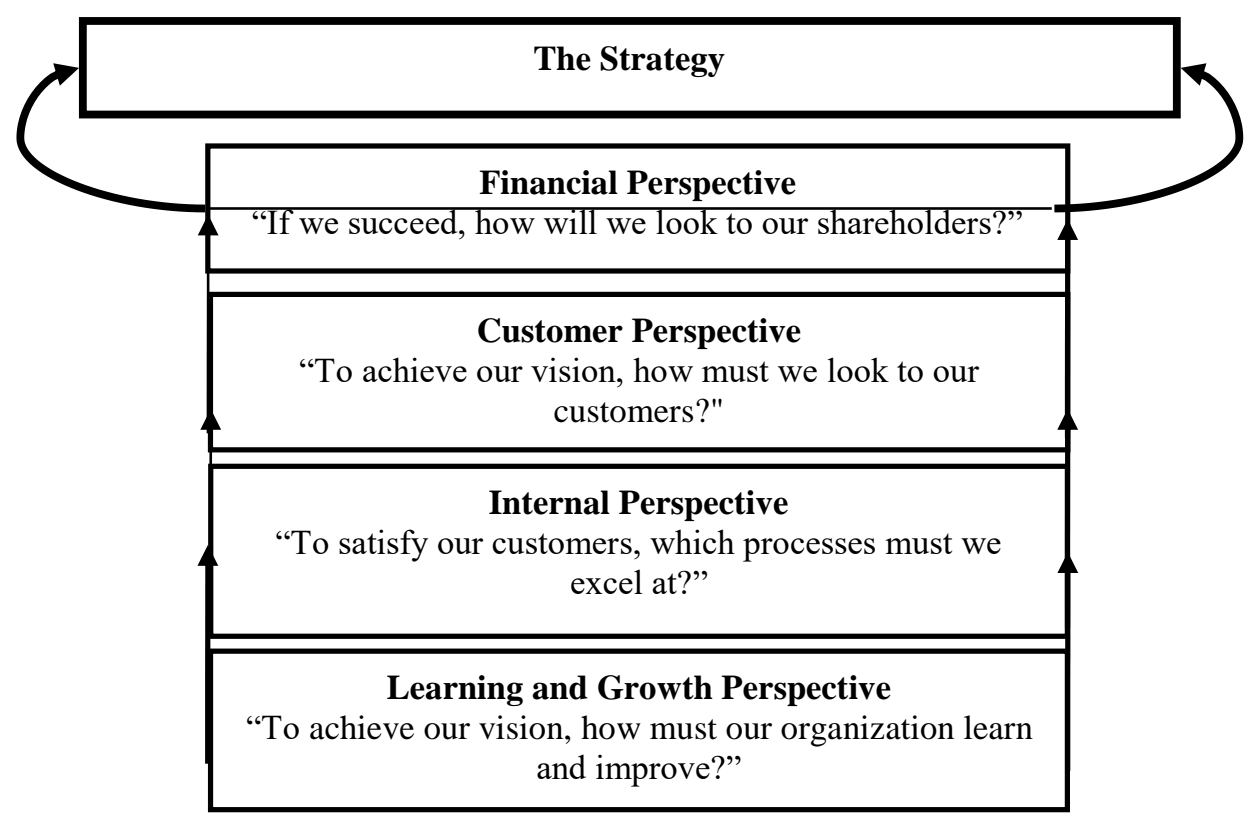

Source: Kaplan, R. and Norton, D. (2004).

The BSC framework in figure (3) has numerous essential elements. First, financial performance, a lag indicator, provides the crucial description of an organization's achievement. Strategy describes how firms be going to generate sustainable growth in shareholder value. Therefore, BSC puts the financial perspective at the beginning of the ladder. Second, in the private sector, the customer is acting two distinctive and complementary roles; Success with targeted customers provides a primary component for better financial performance, paying for a service and getting it. Third, the value proposition of customer is created by the internal business process. The internal business process can be considered as a leading indicator of the enhancement and improvement in the outcomes of the financial and customer perspectives. Finally, Learning and growth objectives depict how employees, technology, and organizational characteristics connected to maintain the strategy. Accordingly, it can be said that learning and growth is considered a lead indicator for customer, internal process and financial performance.

Therefore, many types of organizations in the private sector have followed these important elements in their application of BSC. These include manufacturing organizations (Basuony, 2014a; Fernandes et al, 2006; Hoque and James, 2000; Maiga and Jacobs, 2003), service organizations (Patel et al, 2006; Davis and Albright, 2004; Ittner et al, 2003) and growing and mature organizations (Kald and Nilsson, 2000; Wagner and Kaufmann, 2004; Nielsen and Sorensen, 2004; Malina and Selto, 2001).

\subsubsection{Applications of the BSC in Public, Government and Non-Profit Organizations}

During the last few years, the BSC has been adopted by non-profit and government organizations (NPGOs). One of the obstacles in applying the scorecard in those sectors is the considerable difficulty NPGOs have in clearly defining their strategies. It is abnormal to find non-profit organizations concentrating on a strategy that can be thought of as customer intimacy or product leadership. As a result, scorecards in these organizations tend to be closer to the Key Performance Indicators scorecards (KPI) than true strategy scorecards (Kaplan, 2001b). Therefore, the BSC mainly tends to be a performance measurement system.

The majority of NPGOs had complexity with the original construction of the BSC that positioned the financial perspective at the top of the hierarchy. The success in the financial perspective is not the main objective for most of these organizations; many reallocate the scorecard to set customers or constituents 
at the top of the hierarchy. For a non-profit or government organization, however, the focus is not in the financial perspective when the firms are delivering their mission and objectives. Figure (4) shows the BSC perspectives in public and non-profit organizations.

Figure (4): BSC in Public and Non-profit Organizations

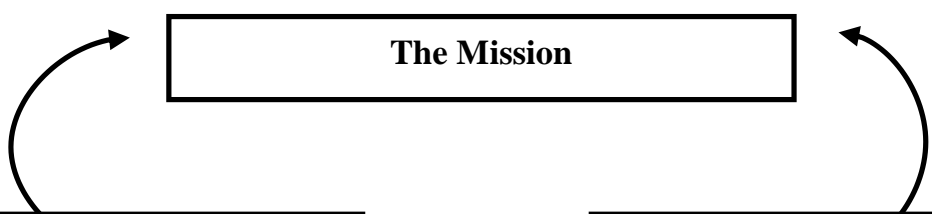

Fiduciary Perspective

"If we succeed, how will we look to our taxpayers (or donors)?"

\section{Customer Perspective}

"To achieve our vision, how must we look to our customers?"

Learning and Growth Perspective

"To achieve our vision, how must our organization learn and improve?"

Source: Kaplan, R. and Norton, D. (2001a).

The process in a non-profit organization is achieved first by donors who offer the financial resources then they pay for the service while another group, the constituents are receiving the service. Organizations place both the donor (fiduciary) perspective and the recipient (customer) perspective beside each other, at the top of their BSC. They develop objectives for both donors and recipients and then identify the internal processes that distribute desired value propositions for both groups of customers (Kaplan, and Norton, 2001b).

Most of the implementations and applications of the BSC that used as a performance measurement are focused on the private sectors (Atkinson and Epstein, 2000; Kaplan and Norton, 2001). However, Ittner and Larcker (1998) depicts that enhancing and improving the efficiency and effectiveness of government operations in the government sector can be achieved through the important role of performance measurement systems. The NPGOs have the experience rising demands for more efficient management of resources and effective decision making (Brignall and Modell, 2000; Brunsson, 1994). The deployment of market-based control models in NPGOs has a force from constituents (Kaplan and Norton, 2001a), local governments (palmer, 1993) and health care agencies (Van Peursem et al, 1995). The comparison of applications of BSC in Private and Public Organizations is shown in table (1). 
Table (1): The comparison of BSC in Private and Public Organizations

\begin{tabular}{|c|c|c|}
\hline The comparison & Private Organizations & $\begin{array}{c}\text { Public and Non-profit } \\
\text { Organizations }\end{array}$ \\
\hline $\begin{array}{l}\text { 1. The benefits of using } \\
\text { BSC }\end{array}$ & Increase shareholder value & Achieve social goals and missions \\
\hline $\begin{array}{l}\text { 2.Usage of BSC } \\
\text { generations }\end{array}$ & $\begin{array}{l}\text { Using all generations of BSC: } \\
\text { - BSC as a performance measurement } \\
\text { - BSC as a strategic management } \\
\text { system } \\
\text { - BSC as a control system }\end{array}$ & $\begin{array}{l}\text { Mainly focus on performance } \\
\text { measurement as a first generation of } \\
\text { BSC }\end{array}$ \\
\hline 3. BSC perspectives & $\begin{array}{l}\text { Use of Kaplan and Norton's four } \\
\text { perspectives }\end{array}$ & $\begin{array}{l}\text { - Use of Kaplan and Norton's four } \\
\text { perspectives } \\
\text { - Use of fiduciary perspective which } \\
\text { reflects the objectives of an } \\
\text { important constituency- the } \\
\text { taxpayers or donors who supply the } \\
\text { funding. }\end{array}$ \\
\hline $\begin{array}{l}\text { 4. Priorities in using } \\
\text { BSC perspectives }\end{array}$ & $\begin{array}{l}\text { Place the financial perspective at the top } \\
\text { of the hierarchy }\end{array}$ & $\begin{array}{l}\text { Place the customer or constituent } \\
\text { perspective at the top of the } \\
\text { hierarchy }\end{array}$ \\
\hline $\begin{array}{l}\text { 5. The customer role in } \\
\text { BSC implementation }\end{array}$ & $\begin{array}{l}\text { The customer plays two distinct roles: } \\
\text { paying for service and receiving the } \\
\text { service which reflect on the internal } \\
\text { processes that serve the customer needs. }\end{array}$ & $\begin{array}{l}\text { - Donors or taxpayers provide the } \\
\text { financial resources where they pay } \\
\text { for the service. } \\
\text { - The constituents receive the } \\
\text { service. }\end{array}$ \\
\hline
\end{tabular}

\section{The Balanced Scorecard and Other Tools}

\subsection{The Balanced Scorecard and Tableau de Bord}

The Tableau de Bord (TDB) is a performance measurement system which emerged in France in the 1930s. The TDB was developed from a tradition of engineers occupying leadership positions in industry and business management, not just in manufacturing areas, but also in finance, banking, services and general management (Bessire and Baker, 2005; Lebas, 1996). Epstein and Manzoni (1998) noted that TDB was developed by process engineers who were looking for ways to improve their production processes by better understanding cause-effect relationships (the relationship between actions and process performance).TDB is conceived as a dashboard such as the one on which aircraft pilots and car drivers observe the speed at which they are going, how many miles they have covered so far, and how much fuel they are consuming.

The TDB was applied at the top management level to give senior managers a set of indicators that would allow them to monitor the progress of the business, compare it to the goals that had been set, and take corrective actions. TDB emerged and evolved to meet the operational needs of managers. Lebas (1996) argued that TDB was established as a coherent concept which firms could implement effectively, although few have completely succeeded in developing all aspects of the theoretical pure model of TDB found in the literature. The TDB involves translating a unit's vision and mission into a set of objectives 
from which the unit can identify its key success factors (KSF), which then are translated into a series of quantitative key performance indicators (KPI). The similarities and differences between the BSC and TDB are indicated in the following four points below.

First, the TDB and BSC try to link top management decisions to the actions of the employees; both operate hierarchically, top-down (Bourguignon et al, 2004). Furthermore, the TDB and BSC translate visions of the organization into objectives and measures. Although they both combine financial and non-financial measures, the French Tableau de Bord tends to overemphasize financial measures and to contain many fewer non-financial measures (Epstein and Manzoni, 1997).

Second, the BSC uses and builds on four perspectives areas of measurement in a single and concise document. The TDB does not explicitly rely on any specific areas of measurement as in BSC but on managers' conceptions of strategy (Bourguignon et al, 2004). Furthermore, in the TDB, measures tend to be gathered internally, inside the organization, rather than externally from customers. BSC focuses on both internal and external aspects and provides a more complete view of an organization's performance (Kaplan and Norton, 1996a; Epstein and Manzoni, 1997, 1998).

Third, the BSC assumes cause-and-effect relationships among the four areas of measurements whereas TDB does not assume any systematic overall link between the strategic areas of measurements (Epstein and Manzoni, 1998; Bourguignon et al, 2004). Kaplan and Norton stated that this assumption is essential because it allows the measurements in non-financial areas to be used to predict future financial performance.

Fourth, Bourguignon et al (2004) stated that BSC links rewards to performance while TDB does not hold employees responsible for the results but rather it provides information about past and future occurrences. Table (2) provides points of comparison between the BSC and Tableau de Bord.

Table (2): The comparison between BSC and TDB

\begin{tabular}{|c|c|c|}
\hline Comparison & Balanced Scorecard & Tableau de Bord \\
\hline 1. The components & $\begin{array}{l}\text { It consists of measures that categorize } \\
\text { four perspectives (financial, customer, } \\
\text { internal process, and learning and } \\
\text { growth). }\end{array}$ & $\begin{array}{l}\text { It consists of measures or indicators that } \\
\text { are called key performance indicators } \\
\text { (KPI) without classifying or categorizing } \\
\text { them. }\end{array}$ \\
\hline $\begin{array}{l}\text { 2. The method of } \\
\text { using the concept }\end{array}$ & $\begin{array}{l}\text { A single brief document that } \\
\text { summarizes the four different } \\
\text { perspectives of the company's } \\
\text { performance }\end{array}$ & $\begin{array}{l}\text { Applying a single document to a whole } \\
\text { company is inappropriate. }\end{array}$ \\
\hline $\begin{array}{l}\text { 3. The relationship } \\
\text { among the } \\
\text { measures }\end{array}$ & $\begin{array}{l}\text { It uses cause- and effect relationships } \\
\text { among four perspectives. }\end{array}$ & $\begin{array}{l}\text { It is not clearly obvious. It may be using } \\
\text { cause-and effect or interdependence } \\
\text { relationships depending on the company } \\
\text { itself. }\end{array}$ \\
\hline 4. Reward systems & $\begin{array}{l}\text { BSC encourages linking rewards to } \\
\text { performance measurement }\end{array}$ & $\begin{array}{l}\text { Rewards are not linked to performance } \\
\text { measurement }\end{array}$ \\
\hline $\begin{array}{l}\text { 5. The degree of } \\
\text { focus and interest }\end{array}$ & $\begin{array}{l}\text { - It focuses on both internal and } \\
\text { external aspects of an organization. } \\
\text { - It concentrates on short and long-term } \\
\text { objectives of an organization by using } \\
\text { both financial and non-financial } \\
\text { indicators. }\end{array}$ & $\begin{array}{l}\text { - It tends to focus on the internal rather } \\
\text { than external aspects of the } \\
\text { organization. } \\
\text { - It concentrates on short-term } \\
\text { objectives of the organization by } \\
\text { overemphasizing financial indicators } \\
\text { rather than non-financial indicators. }\end{array}$ \\
\hline
\end{tabular}


Based on the previous comparison, the researchers conclude that both BSC and TDB have similar features but the BSC is more useful as a comprehensive performance measurement system than TDB.

\subsection{The Balanced Scorecard and Executive Information System}

BSCs differ from executive information system (EIS) solutions in that they are fluid and constantly changing based on how people meet their goals. EIS systems, on the other hand, contain much hardcoded information and require significant maintenance. They also typically focus on measuring lagging indicators while BSC measures include both leading and lagging indicators. Furthermore, EIS applications focus on moving data from a mainframe to individual PCs rather than leveraging the network to distribute information to everyone in the company. As a result, EIS applications have become systems for just a few, not for the masses (Silk, 1998).

When senior management wants to communicate strategy to the masses and get them to digest it, an efficient measure should be used. BSC is designed to today's networked world. It is a model that is designed to gather information from thousands of providers in the front lines, utilizing it at a corporate level and re-communicating and redirecting it. So, everyone in the company can benefit. Therefore, BSC provides communication, performance measurement and management and feedback that helps in the execution of the strategy. Table (3) compares between the BSC and EIS.

Table (3): The comparison between BSC and EIS

\begin{tabular}{|c|c|c|}
\hline Comparison & Balanced Scorecard & Executive Information System \\
\hline 1. The scope & Global for all levels in the organization & $\begin{array}{l}\text { It is limited for specific levels in an } \\
\text { organization }\end{array}$ \\
\hline $\begin{array}{l}\text { 2. The degree } \\
\text { of flexibility }\end{array}$ & $\begin{array}{l}\text { Flexible and changing based on the } \\
\text { organization's goals }\end{array}$ & $\begin{array}{l}\text { Rigid and contains much hard-coded } \\
\text { information }\end{array}$ \\
\hline $\begin{array}{l}\text { 3. The measures } \\
\text { Used }\end{array}$ & Uses both lagging and leading measures & Uses only lagging measures \\
\hline $\begin{array}{l}\text { 4.Relevance } \\
\text { for decision making }\end{array}$ & $\begin{array}{l}\text { Includes both financial and non- } \\
\text { financial indicators }\end{array}$ & $\begin{array}{l}\text { Includes only financial (lagging) } \\
\text { indicators }\end{array}$ \\
\hline
\end{tabular}

The researchers conclude from the previous comparison that the BSC, as a strategic management system, is constructed to tell the story of an organization's strategy and to guide its implementation.

\subsection{The Balanced Scorecard and Budgeting}

Budgeting is one of the few techniques capable of mixing the whole range of organizational activity into a single succinct document. Therefore, budgeting has been the most famous tool used by many organizations. Traditionally, budgets have served as the main internal metrics of performance. The whole measure of performance combines an output measure with an input measure and the budgeting process seeks to keep the two elements in balance. The budgeting process tends to adopt a given level of output or sales and attempts to define the proper level of spending. The similarities and differences between budgets and BSC are indicated in the following four points.

First, the main control objective of budgeting is to set target profits. Limitations on expenditures and revenue targets offer the basis for profit goals (Drury, 2004; Abernethy and Brownell, 1999). The BSC emphasizes strategic goals by setting integrated measures that enable managers to amend operating 
plans and pursue continuous adaptation of strategic initiatives. Therefore, both budget and BSC can be used as a control system.

Second, Briers and Hirst (1990) stated that reward systems have been more implicit than explicit in the budgeting literature. However, Otley (1999) argued that many rewards are being made contingent upon budget achievement. For the BSC, there are more debates in the literature about linking reward systems specifically to scorecard measures. For example, Otley (1999) claimed that the link of reward systems to BSC is neglected where others found a number of ways in which reward systems were linked to BSC (c.f. Malmi, 2001; Kaplan and Norton, 1996a; Bourguignon et al, 2004). Moreover, Speckbacher et al (2003) demonstrated that two-thirds of organizations in their study linked reward systems to the BSC.

Third, as the pace of change continues to go faster in the global economy it is important for firms to move beyond financial performance measures to consider variables that contribute to long-term value formation (Garnes and Hedin, 2005). In the last decade, organizations have shifted away from a single financial control to integrated frameworks to measure performance (Upchurch, 1998). The Budget is considered as an organization's primary financial control document, although, the budget focuses only on financial results and does not necessarily pay sufficient attention to the means by which those results are to be achieved (Otley, 1999). The BSC is considered as an integrated framework that combines lagging and leading indicators. Lagging indicators describe financial performance while, leading indicators describe non-financial performance and are used to forecast future performance.

Fourth, the regularity of revision of a budget depends on an organization's strategy (Govindarajan and Shank, 1992). Companies in growth modes are more likely to revise targets more frequently than companies in mature product markets. The BSC assumes that revisions should be ongoing. The BSC provides employees with real-time information about organization performance. Table (4) shows the comparison between BSC and budgeting.

Table (4): The comparison between Balanced Scorecard and budgeting

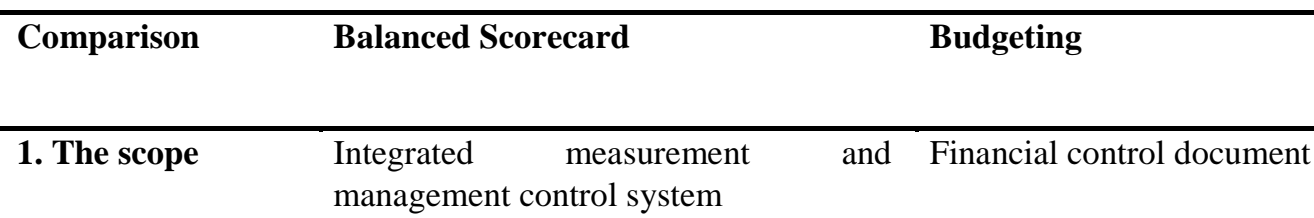

2. The degree of Focus on financial and non-financial Focus on only financial performance focus performance

3. Review and Tied to changes in strategic initiatives Dependent on point in product life-cycle revision

4. Reward systems Not established clearly in the literature

Reward systems contingent upon budget achievement

5. Primary control Strategic goals and ongoing adaptation Target profit orientation objectives

\section{Summary and Conclusion}

This paper presents the evolution of the BSC from performance measurement to performance management. Moreover, the value and contribution of this paper is ascertained by comparing the BSC with other tools from three different points of view. This comparison encompasses the BSC and Tableau de Bord (TDB), executive information system (EIS) and budgeting. Based on the previous comparisons, the paper concludes that both BSC and TDB have similar features but the BSC is more useful as a 
comprehensive performance measurement system than TDB. In addition, the paper concludes from the previous comparisons that the BSC, as a strategic management system, is superior to EIS as it is constructed to tell the story of an organization's strategy and to guide its implementation. Finally, compared with budgeting, BSC focuses on both financial and non-financial measure not only financial measures like budgeting. Moreover, this paper discusses the potential merits of implementing the BSC through understand the managerial applications of the BSC in the private, public and non-profit organizations.

\section{References}

Abernethy, M. A.,\& Brownell, P. (1999). The Role of Budgets in Organizations Facing Strategic Change: an Exploratory Study, Accounting, Organizations and Society, 24(3), 189-204.

Atkinson, A., \& Epstein, M. (2000). Measure for Measure: Realizing the Power of the Balanced Scorecard, CMA Management, September, 23-28.

Basuony, M. A., (2014a). The Balanced Scorecard in Large Firms and SMEs: A Critique of the Nature, Value and Application, Accounting and Finance Research, 3(2), 14-22.

Basuony, M. A., (2014b). The Impact of Management and Strategic Controls on Firm Performance: An Empirical Study on the UK, International Journal of Accounting and Finance, 4(4), 398-419.

Bessire, D., \& Baker, C. R. (2005). The French Tableau De Bord and the American Balanced Scorecard: A Critical Analysis, Critical Perspectives on Accounting, 16(6), 645-664.

Bourguignon, A., Malleret, V.,\& Norreklit, H. (2004). The American Balanced Scorecard versus the French Tableau De Bord: The Ideological Dimension, Management Accounting Research, 15(2), 107-134.

Briers, M., \& Hirst, M., (1990). The Role of Budgetary Information in Performance Evaluation, Accounting, Organizations and Society, 15(4), 373-398.

Brignall, S. \& Modell, S. (2000). An Institutional Perspective on Performance Measurement and Management in the New Public Sector, Management Accounting Research, 11(3), 281-306.

Brunsson, N. (1994). Politicization and Company-ization - on Institutional Affiliation and Confusion in the Organizational World, Management Accounting Research, 5, 323-335.

Davis, S., \& Albright, T. (2004). An Investigation of the Effect of Balanced Scorecard Implementation on Financial Performance, Management Accounting Research, 15(2), 135-153.

Drury, C., (2005).Management and cost Accounting, 6th edition, Thomson, London.

Epstein, M. J. \& Manzoni, J. F. (1997). The Balanced Scorecard and Tableau de Bord- Translating Strategy into Action, Management Accounting, August, 28-36.

Epstein, M. J. \& Manzoni, J. F. (1998). Implementing Corporate Strategy: from Tableaux de Bord to Balanced Scorecards, European Management Journal, 16(2), 190-203.

Fernandes, K. J., Raja, V., \&Whalley, A. (2006). Lessons from Implementing the Balanced Scorecard in a Small and Medium Size Manufacturing Organization, Technovation, 26(5), 623-634.

Garnes, K.\& Hedin, S., (2005). Accounting for lean Manufacturing: Another Missed Opportunity?,Management Accounting Quarterly, 7(1), 28-35.

Govindarajan, V., \& Shank, J. K. (1992). Strategic Cost Management: Tailoring Controls to Strategies, Cost Management, Fall, 14-24.

Hoque, Z. \& James, W. (2000). Linking Balanced Scorecard Measures to Size and Market Factors: Impact on Organizational Performance, Journal of Management Accounting Research, 12(1), 1-17.

Ittner, C. D., \& Larcker, D. F. (1998). Innovations in Performance Measurement: Trends and Research Implications, Journal of Management Accounting Research, 10, 205-238.

Ittner, C. D., Larcker, D. F., \& Randall, T. (2003). Performance Implications of Strategic Performance Measurement in Financial Services Firms, Accounting, Organizations and Society, 28(7-8), 715-741.

Kald, M., \& Nilsson, F., (2000). Performance Measurement at Nordic Companies, European Management Journal, 18(1), 113-127. 
Kaplan, R. \& Norton, D. (1992). The Balanced Scorecard- Measures that Drive Performance, Harvard Business Review, January-February, 70(1), 71-79.

Kaplan, R. \& Norton, D. (1993). Putting the Balanced Scorecard to Work, Harvard Business Review, SeptemberOctober, 70(5), 134-147.

Kaplan, R. \& Norton, D. (1996a).The Balanced Scorecard-Translating Strategy into Action, President and Fellows of Harvard College, Boston.

Kaplan, R. \& Norton, D. (1996b). Using the Balanced Scorecard as a Strategic Management System, Harvard Business Review, January-February, 75-85.

Kaplan, R. \& Norton, D. (2001a) Balanced Without Profit, Financial Management, January,23-26.

Kaplan, R. \& Norton, D., (2001b). Transforming the Balanced Scorecard from Performance Measurement to Strategic Management: Part I, Accounting Horizons, 15(1), 87-104.

Kaplan, R. \&Norton, D., (2001c). The Strategy - Focused Organization, Strategy and Leadership, 29(3), 41-42.

Kaplan, R. \& Norton, D. (2002). The Strategy - Focused Organization: How Balanced Scorecard Companies Thrive in the New Business Environment, Internal Auditor, 59(1), 21-22.

Kaplan, R. \& Norton, D. (2004).Strategy Maps: Converting Intangible Assets into Tangible Outcomes, Harvard Business School Press: Boston, MA.

Lebas, M. (1996).Management Accounting Practice in France. In: Bihmani A, Editor. Management Accounting, European Perspectives, Oxford: Oxford University Press, 74-99.

Maiga, A. S., \& Jacobs, F. A. (2003). Balanced Scorecard, Activity-Based Costing and Company Performance: An Empirical Analysis, Journal of Managerial Issues, 15(3), 283-295.

Malina, M. A., \& Selto, F. H. (2001). Communicating and Controlling Strategy: An Empirical Study of the Effectiveness of the Balanced Scorecard, Journal of Management Accounting Research, 13, 47-91.

Malmi, T., (2001). Balanced Scorecard in Finnish Companies: A Research Note, Management Accounting Research, 12(2), 207-220.

McCunn, P. (1998). The Balanced Scorecard, Management Accounting (British), 76(11), 34-42.

Nielsen, S., \& Sorensen, R. (2004). Motives, Diffusion and Utilization of the Balanced Scorecard in Denmark, International Journal of Accounting, Auditing and Performance Evaluation, 1(1), 103-124.

Oliveira, J. (2001). The Balanced Scorecard: An Integrative Approach to Performance Evaluation, Healthcare Financial Management, 55(5), 42-46.

Otley, D. T. (1999). Performance Management: a Framework for Management Control Systems Research, Management Accounting Research, 10(4), 363-382.

Silk, S. (1998). Automating the Balanced Scorecard, Management Accounting (USA), 79(11), 38-42.

Speckbacher, G., Bischof, J., \& Pfeiffer, T. (2003). A Descriptive Analysis on the Implementation of Balanced Scorecard in German-Speaking Countries, Management Accounting Research, 14(4), 361-387.

Upchurch, A., (1998).Management Accounting: Principles and Practice, 1st Edition, Prentice Hall: Financial Times, England.

Van Peursem, K. A., Pratt, M. J., \& Lawrence, S. R. (1995). Health Management Performance: A Review of Measures and Indicators, Accounting, Auditing \& Accountability Journal, 8(5), 34-70.

Wagner, Stephan, M., \& Kaufmann, L. (2004). Overcoming the main barriers in initiating and purchasing-BSCs, Journal of Purchasing and Supply Management, 10(6), 269-281. 